\title{
USAGE OF NATURAL DYE PLANTS IN KONYA'S ART OF FELT MAKING
}

\author{
Çetin ÖZTÜRK ${ }^{1}$, Salih GİRGIÇ ${ }^{2}$
}

\begin{abstract}
The development of carpet and kilim weaving in Konya has been enabled for centuries by the region's unique climate, geographical position, and livestock breeding traditions. The diversity and abundance of dye plants and insects has been an important influence on the formation of these arts. Stone, soil, minerals, molluscs, and insects were among some of the first raw materials utilized as natural dyes; however, awareness of the expansive potential for colors in plants has led this category of dyes to supercede all others. Plants can produce a palette of hundreds of different colors and shades for use in folk arts, including carpets, felts, and ceramics. Methods for deriving dyes from plants vary between regions, and techniques are kept as closely guarded secrets, transferred between the generations with a profound sense of confidentiality. In this study, the plant dyes and methods of application particular to felt art in Konya, were investigated. The experience of Keçeci (felt artist) Mehmet Girgiç concerning the use of natural dye plants konya's art of felt making was recorded.
\end{abstract}

Keywords: Felt, Wool, Konya, Dye Plants, Mehmet Girgiç

\footnotetext{
${ }^{1}$ Dr.Öğr.Üy., Necmettin Erbakan Üniversitesi, Güzel Sanatlar Fakültesi, Geleneksel Türk Sanatları Bölümi, cozturk(at)gmail.com

${ }^{2}$ Keçe Sanatçısı, kececikonya(at)gmail.com

Note: The abstract of this work was published in the abstract book of the Symposium on International Medical and Aromatic Plants held in Konya between 10-12 May 2017.
} 


\title{
KONYA KEÇECILIĞíNDE BOYAR BITKI KULLANIMI
}

\begin{abstract}
ÖZ
İklim ve coğrafi konumundan dolayı Konya ovasında yüzyıllardan beri küçükbaş hayvancılığının yapılması beraberinde halı ve düz dokumacılığının gelişmesini sağlamıştır. Konya'nın boyar bitkiler ve böcekler bakımından oldukça zengin bir bölge olması da bu sanatların gelișiminde önemli bir etkendir. Doğal boyacılığın ilk hammaddeleri boyarmadde özelliğine sahip bazı taş, toprak ve maden çeşitleri ile bazı yumuşakça ve böcek türleridir. Ancak bitkilerdeki renk çeşitliliğinin keşfi bitkinin tamamının veya bir bölümünün boyamacılıkta kullanımına yol açmıştır. Doğadaki yüzlerce çeşit bitkiden üretilen farklı renk ve renk tonları Halıcılıkta, Keçecilikte, Çinicilikte ve birçok kültür varlığımızda kullanılmıştır. Bitkinin farklı bölgeleri kullanılarak ve farklı yöntemler uygulanarak ortaya çıkan renklerin, elde edilme yöntemleri bir sır gibi saklanmış, nesilden nesile büyük bir gizlilikle aktarılmıştır. $\mathrm{Bu}$ çalışmada Konya Keçeciliğinde bitkisel boyaların kullanımı ve renklendirme yöntemleri araştırılmış, Keçeci Mehmet Girgiç'in Konya keçeciliğinde bitkisel boyar madde kullanımı ile ilgili tecrübeleri kayıt altına alınmıştır.
\end{abstract}

Anahtar Kelimeler: Keçe, Yün, Konya, Boyar Bitki, Mehmet Girgiç 


\section{INTODUCTION:}

"Felt" is a coarse fabric used to make floor coverings, hats, and clothing, which is obtained by agitating wool (with the occasional addition of alternative fibers like cotton) in a wet environment process that binds individual fibers together by encouraging them to interlock at a microscopic level (Begiç 1999:5).

In the traditional method, felt is made by rolling animal fibers such as sheep, llama, alpaca and camel, or goat hairs such as mohair, cashmere, water, soap and heat in alkaline environment $(\mathrm{pH}: 10-11)$ and working them together. Traditional felts have very strong heat, moisture, electricity, light and sound insulation properties (Y1ldırım 2013: 6).

When the art of felt was brought to Anatolia from Central Asia by Seljuk Turks, Konya became its center, and met the needs of the Mevlevi dynasties (e.g. Dervish Headdress, Haydari, Arakiye, Conical Hat and Floor Coverings). (Begiç 1999:12).

The fact that Konya is rich in dye plant diversity and the spread of small sheep breeding in the region enabled the art of felt making to continue in Konya for centuries. The multitude of people involved in felt production established numerous workshops close to one another, prompting the naming of their streets in honor of these craftsmen. The name of the street to the left of the municipal new market in the vicinity of Kayiklikahve (now Balıkçlar Hotel) in Konya was "felt makers" street (Begiç 1999:11). In contemporary Konya, emerging technology and industrialization have negatively impacted the art of felt, causing this profession to be forgotten as it is in many traditional crafts.

Nowadays, Konya has only three active feltmaking workshops. One of these workshops is the shop of Mehmet Girgiç, who is known as Keçeci Mehmet in Konya and was honored as one of seven Turkish Living Human Treasures by UNESCO in 2010.

Mehmet Girgiç inherited the felt making tradition from his grandfather at a very young age, and made original works reflecting traditional handmade works while experimenting with changes in color, motif, shape, size and immortalizing his products made with natural dyes. This research investigates Mehmet Girgiç's traditional dye making techniques for felt art production. Mehmet Girgic, is felt artist, and his sons are seen in the picture 1 . 


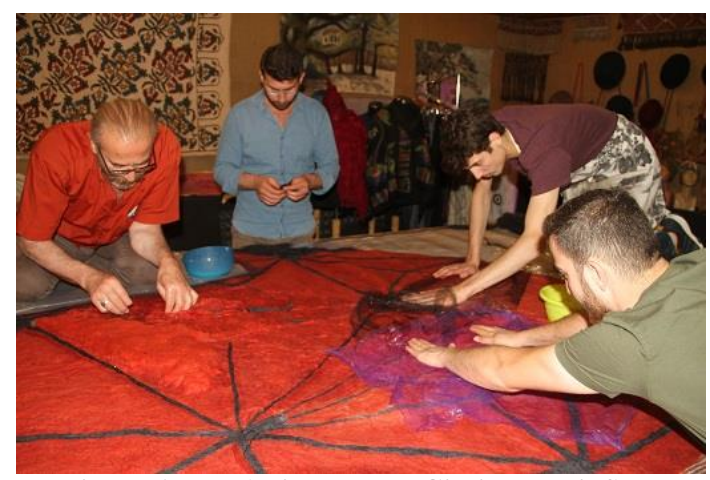

Picture 1: Felt Artist Mehmet Girgiç and His Sons

\section{MATERIAL AND METHOD:}

There are many plants containing dyestuffs in nature. However, the plants that provide both interesting colors and the high degree of fastness to light, water and washing yield the most valuable dyes (Akan 2007: 16).

In Konya, nine dyestuffs are used in felt production. These are Ruby, Reseda, Pomegranate, Sumac, Walnut, Cyprus Oak, Rhamnus, Cochineal and Indigo. Cochineal dyes are usually derived from a female insect that grows in South America, while other dyes are derived from plant dyes in the nature. With the exception of indigo, which is grown in India, the plants discussed here are grown in Konya. Felt artist Mehmet Girgiç has reported that each color has its own special formula and preparation.

Ruby (Rubi a Tinctorum L.): Ruby, also known as madder, is an herbaceous perennial plant that grows from 1 to 2 meters in height. It is found in fertile soil, and characterized by a rhizome and pale yellow flowers. The plant sheds its flowers in fall but will bloom again each spring. Ruby grow in sets of 4 or 6 and sprout from the stem from the same node in a circular pattern (Karadağ 2007: 72). A Ruby plant is seen in the picture 2 . 


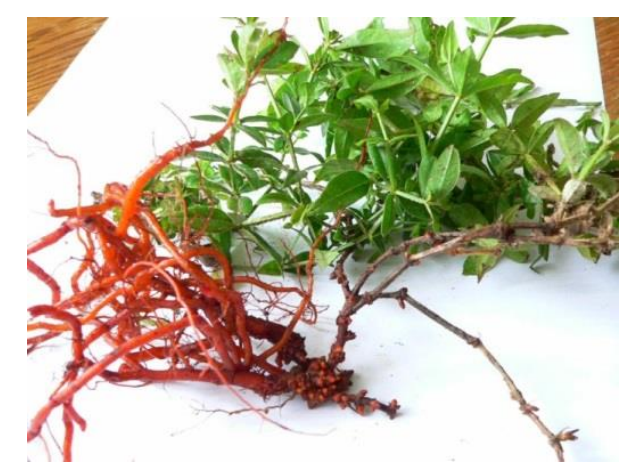

Picture 2:Ruby Plant ( Rubia Tinctorum L.)

The longer Ruby stands on the soil, the more her roots grow, the more her dyestuffs increase; and as a consequence, mature ruby roots generally yield more dye than young roots. These roots are harvested from the soil at the beginning of the summer or in the autumn (in October). Harvested roots are referred to by the name of the season in which they are dug up, because this relays information about potency of their dye. The amount of dye in the roots varies between 1 and $4 \%$ according to the conditions of the region where the plant grows. The ruby root is dark red, the living cortex region is yellow, the wood part is yellowish white, and the core region is yellow orange color (Kayabaş1 2004: 80).

Ruby is also known as 'Dilkanatan plant' in Anatolia. The ruby roots used to obtain the red color are first dried then ground in the mill, put into a net, transferred to a dye pot, and covered with water. Wool that has been left overnight in an alum mordant and subsequently drained is then added to the simmering ruby concoction for dying. A dry ruby plant and its wetting stage are seen in the pictures 3 and 4 . 


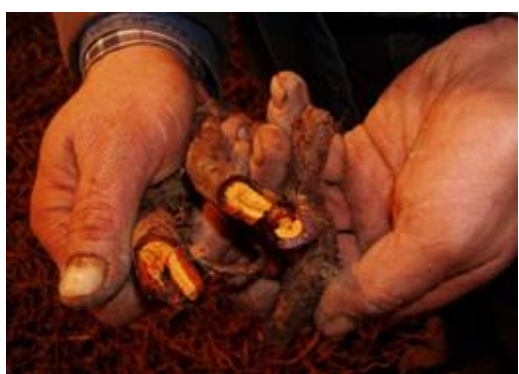

Picture 3: Dried Ruby.

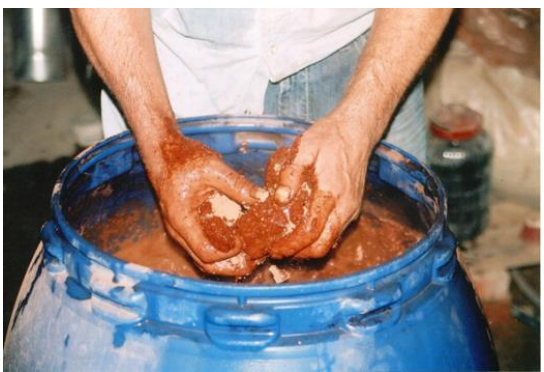

Picture 4: Wetting Stage Of Ruby

The mixture is simmered for about 4-6 hours according to the desired color tone at about $90{ }^{\circ} \mathrm{C}$. Then, the dye pot is left to cool down. After the temperature of the dye pot has reached $60^{\circ} \mathrm{C}$, the colored wool is removed from the dye pot, rinsed with plenty of water, and hung to dry. Red wools obtained from Ruby plants is seen in the picture 5 .

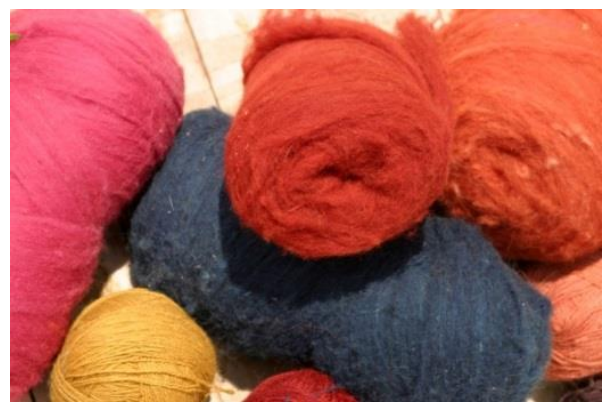

Picture 5: Red wool obtained from Ruby

Reseda (Reseda Luteola L.): Reseda, also known as weld or dyers rocket is a biennial plant, meaning it takes two years to mature, and can grow up to 150 centimeters in height. Only the rosette is formed in the first year, and development of the flower stalk is completed in the second year. In June, Reseda opens spiky flowers that follow the sun, like those of a sunflower. At the end of June, the flowering ends. There is no need for fertile soil for the plant to grow; reseda can grow in moist, sandy and pebbly soil, and spreads easily in the wild. It can even be seen growing spontaneously a year later on new roadsides. This plant is widely cultivated, especially in West Asia and Mediterranean countries (Karadağ 2007: 82). ). A Reseda plant is seen in the picture 6 . 


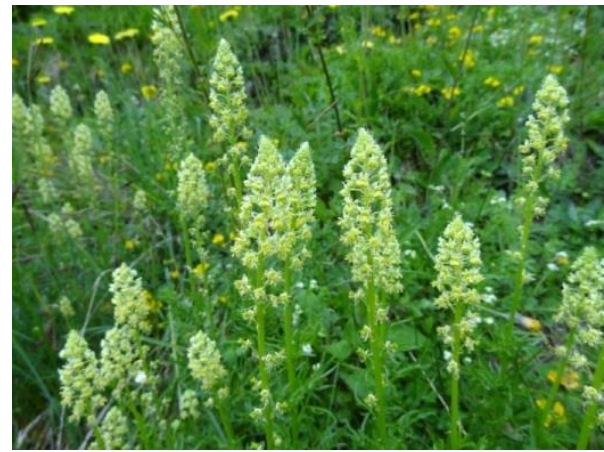

Picture 6: Reseda Plant

Reseda imparts yellow colors and tones and is used in tandem with an alum mordant, pomegranate skins, walnut and madder to get a gold tone.

The complete Reseda plant is first dried then ground in the mill. The ground plant matter is then soaked overnight with the mordanted wool. The wool and water are transferred to the prepared dye pot after filtration. The mixture is simmered for about 4-6 hours according to the desired color tone at about $90{ }^{\circ} \mathrm{C}$. Then the dye pot is left to cool down. After the temperature of the dye pot has reached $60{ }^{\circ} \mathrm{C}$, the colored wools are removed from the pot, rinsed with plenty of water and dried in the shade.

Pomegranate (Punica Granatum L.): Pomegranate is a small evergreen tree or shrub with sparse branches, which can grow from 5 to 6 meters in height. The leaves grow in a strip formation. Around May-June, the tree's vermilion flowers bloom. The foliage that occurs in autumn is first green, then yellow and red (Karadağ 2007: 86). A Pomegranate shells is seen in the picture 7.

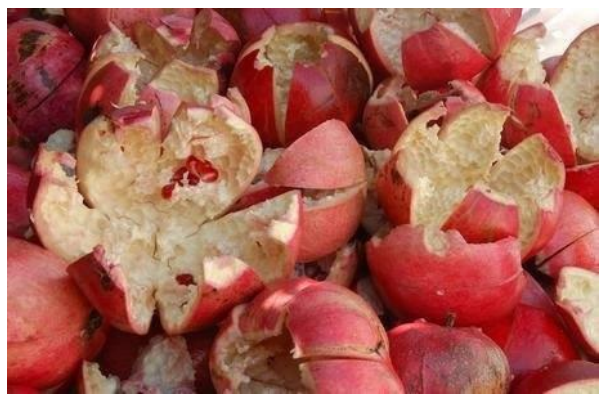

Picture 7: Pomegranate

The fruit skins are used by drying and then grinding them to same size grade employed for wheat. Although the pomegranate yields yellow tones, it is added as a 
natural mordant, fixative as well as color shifter for other dyes. It produces clearer color tones and brighter appearance.

Sumac (Rush Coriaria L.): Sumac is a tree that grows to 1-3 meters in length. The young branches produce compound leaves and red hairy fruiting bodies. The tree can be distinguished by its green round crest and densely branched shrub appearance.

The flowers are greenish-white in color. The juicy fruits with kernels resemble a sphere with a diameter of 4 to 6 millimeters. When the fruit is ripe, it is red colored and the taste is sour. Sumac fruit is used in spices and both its leaves and fruit are used in both dye making and tanning. Sumac is found both in Western and Southern Anatolia, in the Black Sea, Mediterranean and Marmara regions, growing individually or in groups (Karadağ 2007: 100). A Sumac plant is seen in the picture 8 .

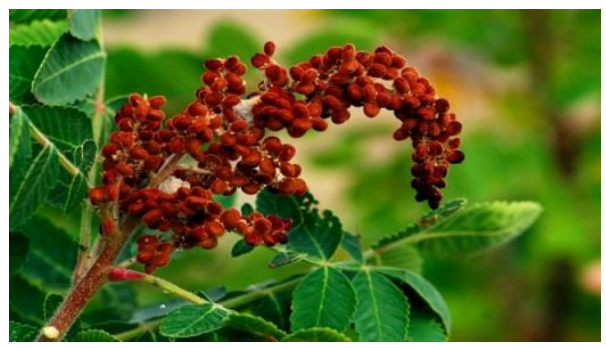

Picture 8: Sumac Plant

Walnut (Juglans Regia L.): Walnut is a deciduous, thick-branched tree with a wide crest, that can grow up to 25-30 meters. Though most commonly known for its edible nuts, it is the leaves and the outermost green peels that surround the nuts that are used in dye making. These elements of the plant are dried and ground for use as a dye (Karadağ 2007: 36). The use of walnut shells to produce brown pigment is widespread, not just in Turkey but also in Europe, Asia, and the Americas. A Walnut Leaf and Walnut is seen in the picture 9. 


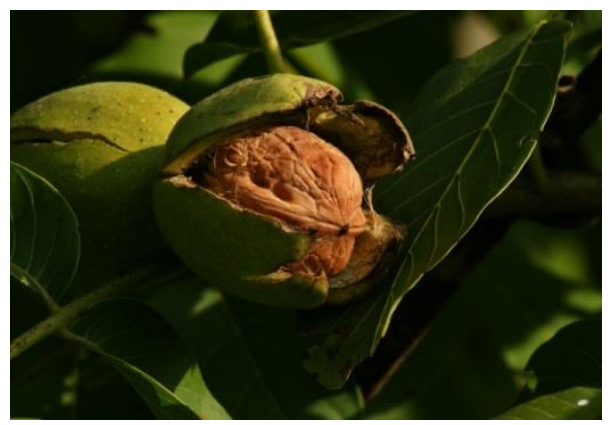

Picture 9: Walnut Leaf and Walnut

In felt making, walnut hulls are used to obtain both brown and black dyes. Black dye is created by making a dye bath with walnut skins and a small amount of gallnut. The combination is transferred to a dyepot and covered with water. Wool that has been mordanted with iron is then added to the dye pot. After leaving for 1 day at room temperature, feltmakers will apply a low heat beneath the dyepot until the mixture reaches $90{ }^{\circ} \mathrm{C}$. Every half an hour the wool is thoroughly mixed in the dyepot, and this process carries on for 4-6 hours. After the water temperature has been cooled to $60^{\circ} \mathrm{C}$ in the dye pot, the colored wools are taken from the pot, rinsed and dried in the shade, as sun exposure is detrimental to the potency of natural dyes.

Gallnut (Quercus İnectoria Olivier): Gallnut, which has the widest distribution in the Marmara and Black Sea regions, is found on the Quercus infectoria tree, also known as Aleppo Oak. These large trees grow to a height of 12 meters and diameter of 80 centimeters. Thickened, tannin-rich galls are formed by the trees as a resistance to punctures made by insects. In June-July, female Gallnut wasps ((Cynips insana (West.) Mayr)) lay their eggs in tree branch buds, prompting the formation of gallnuts. Around the releasing eggs occur fine membrane fatty substances develop, sugar and shellac (gal) which have rich protein nutritional layer. There is also a hard protective layer outside the nutrition layer. The two layers constitute gallnut. The resulting gallnut is 1,5 to 2 centimeters in diameter and round (Karadağ 2007: 78). The Gallnuts are seen in the picture 10 . 


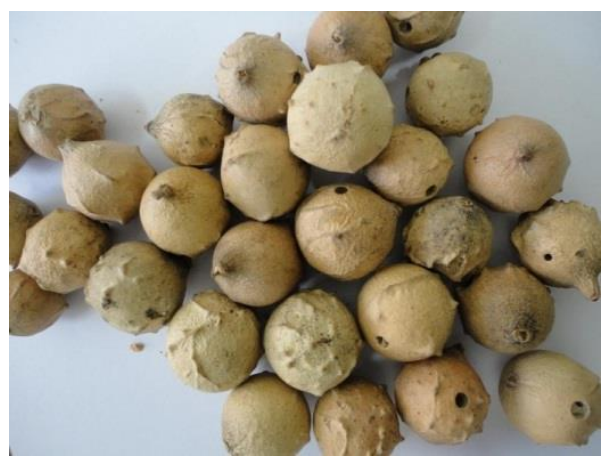

Picture 10: Gallnuts

There is a color between the dirty yellow and brown from gallnut. This type of painting is also known as "tetre" painting in public. The line is painted with wool ironalum or iron-containing sludge to obtain black color (Karadağ 2007:78). The tone of the picture is obtained with gallnut. Gallnut is used to obtain different color tones by mixing with other plants in small quantities. Wool dyed in gallnut which is mordanted with iron-alum or iron-containing sludge achieves a black color.

Rhamnus (Rhamnus Petiolaris Boiss): Rhamnus, also known as the golden tree, alacehir, painter's stitch, and akdiken, is a hedge in the form of a shrub that can grow up to 3 meters. It grows at altitudes of 1000 to 1300 meters in mountainous, hilly, rocky places, on sunny slopes, in forest openings under sparse coverage or in borders. The outer shell of the fruit, which grows to 6-7 millimeters in diameter, is brown, and the inside is a yellow color (Karadağ 2007: 34). A Rhamnus Plant is seen in the picture 11 .

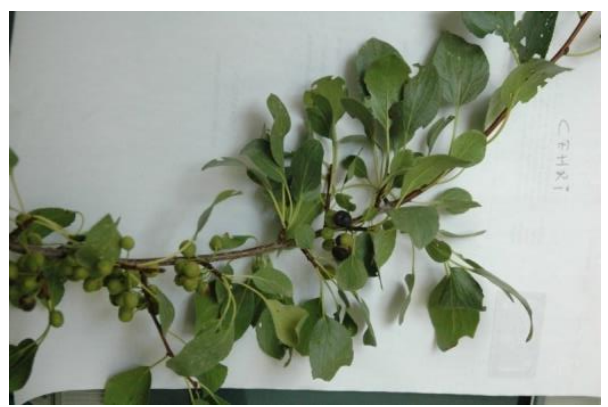

Picture 11: Rhamnus Plant 
Rhamnus is used to obtain a yellow color. Rhamnus fruit is put into a net with a small amount of pomegranate and gallnut, and is then transferred to a dyepot and covered with water.

Wool mordanted with alum is added to the dye pot. The wool and dye plant are left for one day at room temperature. The following day it is simmered. Every half hour the wool is thoroughly mixed in the dye pot When boiling starts, it continues for another half an hour and then shut down. After the water temperature has been cooled to $60^{\circ} \mathrm{C}$ in the dye pot, the colored wools are taken from the water, rinsed and dried in the shade away from sun.

Cochineal $($ Coccus Cati Auct. $=$ Dactylopius Coccus Costa): The cochineal beetle is native to Central America, and lives on Nopal Cochineal cactus. On the cactus, the reddish brown color of the beetle transforms into a dark red color.

The dyestuff in this case, carminic acid is found only in female Cochineal beetles. The female beetle has no wings and can not fly. They can not move despite having feet, but instead latch on to cactus pads and subsists parasitically off moisture and nutrients from the plant (Karadağ 2007: 70). A Cochineal Beetle is seen in the picture 12 .

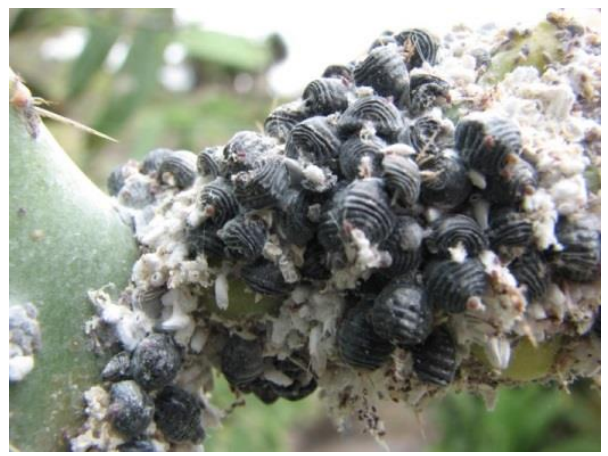

Picture 12: Cochineal Beetle

Cochineal beetle is used to obtain pink colors and tones. Dried Cochineal beetles are crushed and mixed directly into the dye pot which has been heated to 50 ${ }^{\circ} \mathrm{C}$. Wool, mordanted with alum is spun out and added to the dye pot. The wool is then simmered over low heat for 10 minutes and then turned off. When the water temperature is $60{ }^{\circ} \mathrm{C}$, the colored wools are removed from the dye pot, rinsed and dried.

Indigo (Indigofera tinctoria L.), a tropical plant that grows in India, is a dye that gives a blue color. The structure of the dye is an aromatic compound derived from the combination of two indoxyl molecules. Indigo plants have been cultivated in 
India for 4000 years. In the 12th century, Indigo was first exported to Europe as a pigment. At the end of the century it was introduced as a dyestuff by Marco Polo and started to be used by Venetian painters.

In the 16th century, indigo became abundantly and cheaply available in Europe, and its use became very widespread. At the end of the century, Isaac Newton gave the name of indigo to one of seven colors when he obtained the spectrum of the sunlight. There are various plants that produce indigo dye. One of these, indigo grass (Isatis tinctoria L.), has been known for a long time (Deveoğlu 2011: 30). Indigo is now grown both in Europe and in Anatolia, and grows wild in Central and Western Anatolia today.

In order to use the indigo as a dyestuff, a water soluble derivative, indican is obtained by fermenting leaves in water. The derivative is a hydrolyzation of glucose and indoxyl. A strong base such as lye is added to the solution to achieve blue stains from the percipitates. Indigo has not only been used in textile dyeing, but also since ancient times as cosmetics, bleeding inhibitors, and to address inflammation, cancer and ulcers (Deveoğlu 2011: 30). An Indigo plant is seen in the picture 13.

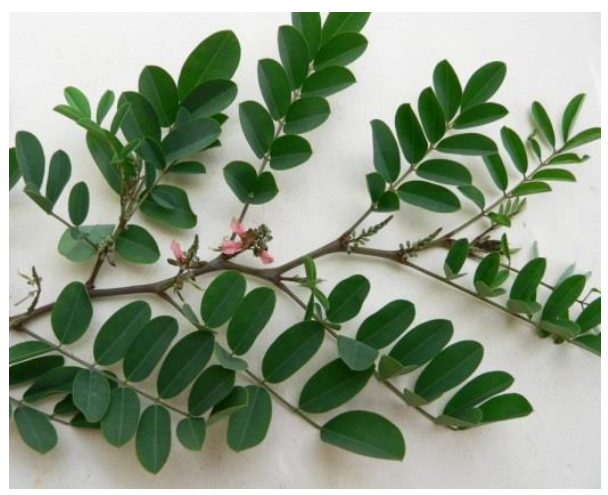

Picture 13: Indigo plant

Indigo produces various shades of blue. To obtain green and turquoise shades in wool, first the wools are dyed yellow, and then the yellow wool is dipped in indigo for the length of time necessary to reach the desired color tone.

Alkaline (ammonia/base) is added to adjust the $\mathrm{pH}$ of the liquid to about $(7,9$, 11) when the temperature of water in the dyepot reaches $60{ }^{\circ} \mathrm{C}$ (K1z1l 2001: 43). Then, indigo is added in the correct proportion to reach the desired shade, along with exactly 2 times sodium hydrosulfite $\left(\mathrm{Na}_{2} \mathrm{~S}_{2} \mathrm{O}_{4}\right)$. The temperature of the boiler should not exceed 60 to $80{ }^{\circ} \mathrm{C}$. 
After the dye stuff is added to the dye pot, the water is stirred carefully, without introducing air. The wool is then added carefully. Then the wool is removed after 5 minutes, turning blue as it oxidizes. Since the color of the dipped wool will be darkened with each dip, the process and length of time for dipping wool into the boiler is determined according to the desired color tone. After dyeing, the wools are rinsed with plenty of water and dried outdoors in the shade (K1z1l 2001: 43). The colored wools prepared with natural plant dyes and some works from Mehmet Girgiç's Workshop are seen in the pictures 14 and 15, respectively.

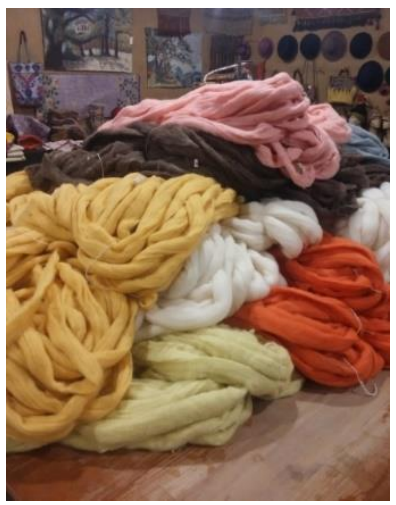

Picture14: Colored Wools Prepared with Natural Plant Dyes
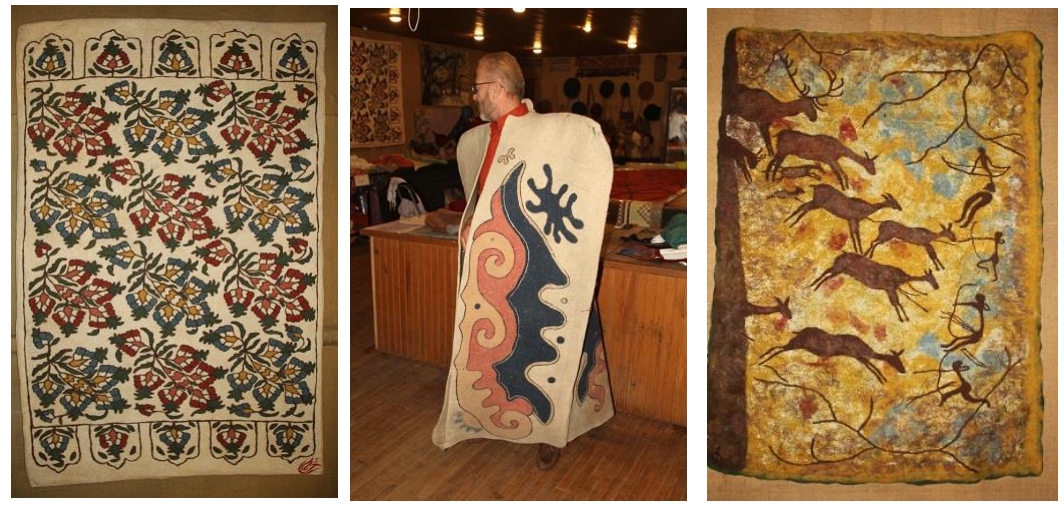

Picture15: Works From Mehmet Girgiç's Workshop 


\section{CONCLUSION:}

Even though its history dates back to the time of the Seljuks, the art of felt making, which is one of the forgotten professions today, has reached the stage of reexistence. Mehmet Girgiç, an artist from the Ministry of Culture, known for his name Keçeci Deli Mehmet (felt maker), is one of the few people in Konya who continue to practice the felt works that his grandfather profession, in accordance with traditions. $\mathrm{He}$ is one of the last Turkish artists to produce natural paint materials for felt art. In this study, the vegetable dyes used in Konya felt works, the preparation techniques of these materials, the methods of dying and coloring of wool and the practices of Konya felt arts are explained in detail. The information about Konya felt arts, obtained through the study, will play an important role in its transporting to the future.

\section{REFERENCES:}

Akan, M. (2008). Uygun Renk, Işık Ve Sürtünme Haslı̆̆ı Değerlerine Sahip Bitkisel Boyalarla Boyanmış Ilmelik Yün Ípliklerinde En Az Kopma Mukavemeti Kaybına Yönelik Boyama Yönteminin Geliştirilmesi. Ankara Üniversitesi Fen Bilimleri Enstitüsü.

Begiç, H.N. (1999). Konyalı Keçe Sanatçısı Mehmet Girgiç ve Eserleri. Selçuk Üniversitesi Sosyal Bilimler Enstitüsü.

Deveoğlu, Ozan ve Karadağ, Recep (2011). Genel Bir Bakış: Doğal Boyarmaddeler. Marmara Üniversitesi Fen Bilimleri Dergisi, 23, 21-32.

Karadağ, R.(2007). Doğal Boyamacılık. Ankara: Geleneksel El Sanatları ve Mağazalar İşletme Müdürlüğü.

Kayabaşı, Nuran ve Dellal, Gürsel (2004). Koyun Irklarından Elde Edilen Yünlerin Kökboya (Rubia tinctorum L.) ile Verdikleri Renklerin Işık Haslık Değerleri Üzerine Bir Araştırma. Yüzüncü Yıl Üniversitesi Tarım Bilimleri Dergisi, 14, 79-83.

Kızıl, Süleyman ve Arslan, Neşet (2001). Bazı Çivit Otu (Isatis tinctoria L., Isatis constricta Davis) Türleri ile Yün Hali İpliklerinin Boyanması ve Elde Edilen Renklerin Bazı Haslık Değerlerinin Belirlenmesi Üzerine Bir Araştırma .Tarım Bilimleri Dergisi,7, 42-47.

Yıldırım B. (2013). Kültürümüzde Keçe Var. İstanbul: (Yy). 